\title{
Youth in regional labor markets: opportunities and limitations of sustainable employment
}

\author{
Larisa Viktorovna Sankova \\ Yuri Gagarin State Technical University of Saratov \\ Department of Labor Economics and Production Complexes \\ Saratov, Russia \\ sankovalv@sstu.ru
}

\author{
Ekaterina Dmitrievna Bogachenko \\ Yuri Gagarin State Technical University of Saratov \\ Department of Labor Economics and Production Complexes \\ Saratov, Russia \\ ekaterinab0208@gmail.com
}

\author{
Liliya Alekseevna Otstavnova \\ Yuri Gagarin State Technical University of Saratov \\ Department of Labor Economics and Production Complexes \\ Saratov, Russia \\ liliotstav69@yandex.ru
}

\begin{abstract}
The competitiveness and sustainable development of Russian regional economy is largely determined by the effectiveness of using innovative labor potential of the population. In this context, special attention should be paid to the trends in developing youth segments in regional labor markets, since this category of employees is the most dynamic, mobile and active, rapidly adapting to constantly changing business and labor demand conditions. At the same time, youth labor markets play a specific role in balancing the development of regional labor markets. The article considers the condition of youth in the regional labor markets and suggests approaches to assessing the deficit of decent work for young people. Interregional differences in major indicators characterizing the sustainability of youth employment, including pre-crisis and post-crisis stages, are identified. The most notable inter-group transitions are recognized. Identifying the parameters of youth employment stability and its profiles sensu trends in innovative development of the regions will facilitate better understanding of functioning patterns of youth segment in regional labor markets as well as development of comprehensive regulation measures.
\end{abstract}

Keywords - youth employment, labor market, unemployment, region, sustainability

\section{INTRODUCTION}

Young people are the main source of innovative ideas emerging in all spheres of the society and its economy. First, youth is the most dynamic, mobile and active category of the workforce, quickly adjusting to constantly changing business conditions. Second, young people are at higher risk compared to other workforce categories, since they are facing greater challenges and more serious risks on the global and regional levels. Third, young people are the key source for rotation and new entrants into the labor force. In contemporary Russia, young workers constitute $22.9 \%$ of the total workforce. However, youth labor markets play essential role in sustainability of the regional labor markets.

Transformations emerging on the youth labor market can be described by a combination of several trends: informatization, virtualization, globalization, and individualization of labor relations; flexibilization and development of non-standard collaboration forms and coordination of interaction between the labor market entities. The emerging innovative type of employment with its immanent features (such as flexibility, new forms and types of employment, continuous innovations in the various aspects of social and labor relations), first and foremost affects the youth segment in the labor market which has to match specific demands, including social and work experiences and patterns of competitiveness required for new sectors of economy.

Regarding worldwide trends typical of labor markets in general, it should be emphasized that, according to the data provided by the "World Employment and Social Outlook: Trends 2015", the labor market increases annually by 40 million people. As a result, by 2030 given demographic trends will result in necessity to create over 600 million jobs across the world economies. Most likely, these jobs will be primarily created in the service sector. Meanwhile, the service sector remains inhomogeneous in terms of youth employment opportunities.

In Russia, as well as globally, the level of youth unemployment is higher than amid other age groups (Fig.1), which proves the necessity to create conditions for sustainable employment opportunities among the young people. We can agree with the statement that "high level of youth unemployment in the developed and developing countries, as 
well as in Russia, is one of today's challenges that will prevent sustainable development of economic systems [3]".

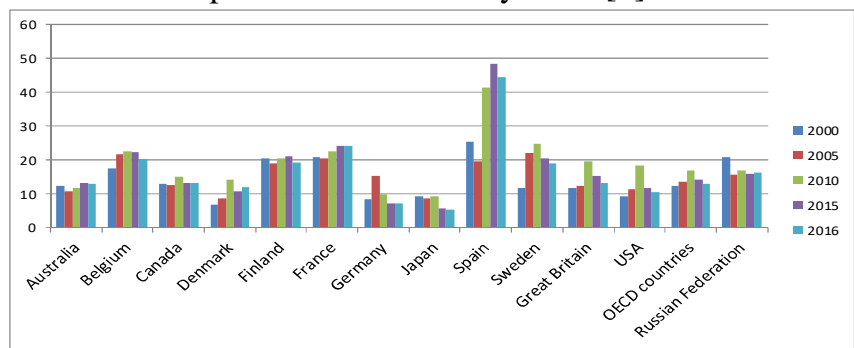

Fig. 1. Youth unemployment rate (15-24 years) for OECD countries and Russia, \% (constructed according to [4]).

Regional labor markets across Russia have significant differences for several parameters, including the index of youth employment. Generally, the situation in the youth segment of the labor market reflects the features common to the overall labor market model, i.e. discrepancy between standard and actual parameters, coupling of tight regulation standards with insufficient enforcement norms, high flexibility and actual mobility, and dominance of informal institutions (R.I. Kapelyushnikov).

The status of youth on the labor markets is characterized both by general features (common to all the developed countries and regions) and specific processes in employment and unemployment spheres, determined by restrictions emerging on the local level. Specifics of the pioneering stage in the careers of youth on the labor market determines the need for choice relating "employment and accepting a lower wage (on the primary labor market) vs. unemployment." The processes of supply and demand on the regional labor markets influence achievement of equilibrium in the youth labor market segment. K Clark and L. Summers describe the general trend, and emphasize that the growing youth unemployment stems from shortage of work places and shifting attitudes of young workers on the labor market. As a rule, the researchers consider these factors as primarily to determine the situation on the youth labor markets.

In our view, while investigating the issues of employment opportunities and unemployment amid youth, it is essential to consider demographic trends and pressure on the labor market in the short- and long-term perspectives. Thus, according to demographic forecasts by the Russian Statistics Agency made up to 2030, Russia will go through dramatic downsizing of young people up to 25.6 million in 2025 , i.e. by $27.3 \%$ compared to 2012. Meanwhile, in the recent decade there was a decrease in the number of young people aged 15 to 29 . Likewise, market opportunities have discouraged youth to enter into the labor force, in particular within the age groups 15-19 and 20-24. We must also certify a decrease in the number of young people enrolled in the various training programmes provided by educational institutions. The above mentioned processes to a varying degree affect the regional labor markets, which proves the necessity for a detailed analysis of opportunities and barriers to sustainable youth employment in order to set up a package of 'selection' measures on the regional levels.

\section{MATERIALS AND METHODS (MODEL)}

Our research methodology is based on the quantitative and qualitative analysis of youth employment opportunities. The analysis used the data from the official statistics of the Federal Statistics Agency of the Russian Federation.

Let us consider the trends of youth employment in terms of structural-functional and dynamic approaches. Analysis of the age structure of employed population allows us to assume that the years after 2008 the rate of youth employment in Russia has decreased, and the ratio of economic activity amid young people tends to fall. The given tendency is clearly troublesome considering the need to reinforce the labor and innovative potential in Russia. In particuolar, significant reduction was surveyed in the age group of 20-24 (from 57\% in 2008 to $51.6 \%$ in 2014), i.e. the crisis conditions raised a series of challenges for the 'primary' employment of youth. Regarding the age group of $25-29$, the proportion of employed is much higher compared to the general employment ratio (Fig. 2). Considering the structure of employed population in terms of age groups, the tendency of youth employment is clearly downwards in the age groups of 20-24 and up to 20 years, whereas the employment rate goes up in the age group of 2529 year olds.

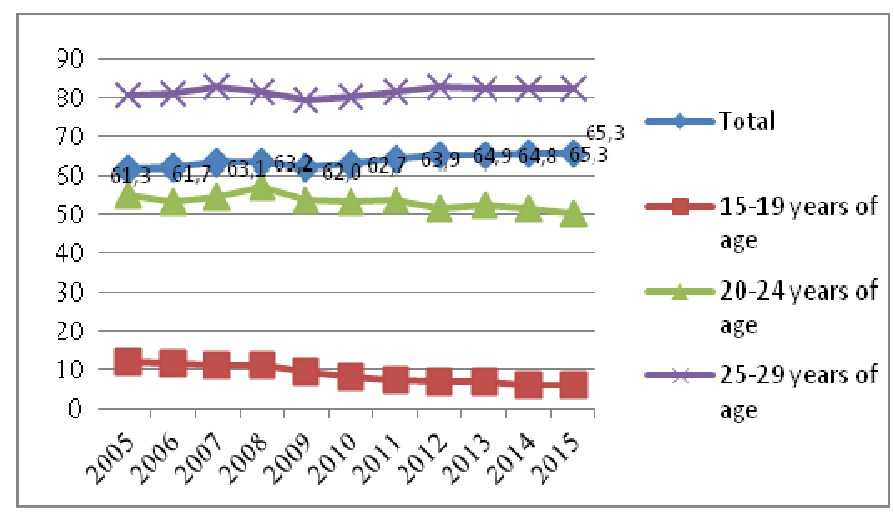

Fig. 2. Youth Employment rate by age groups, \% [2]

The highest proportion of youth employment is observed in the North Caucasian and Siberian Federal Districts. The lowest ratio from the total rate of employed in the youth segment of 20-29 year olds is observed in the Central Federal District. In the period after 2011, the ratio for the youth segment in the regional labor markets of the Russian Federation tends to fall.

Assessment conducted by the areas shows that within the general unemployment picture, the highest rate of youth unemployment is in the North Caucasian Federal district, whereas the lowest rates are observed in the Central, Southern and Far Eastern districts (Fig. 3). 


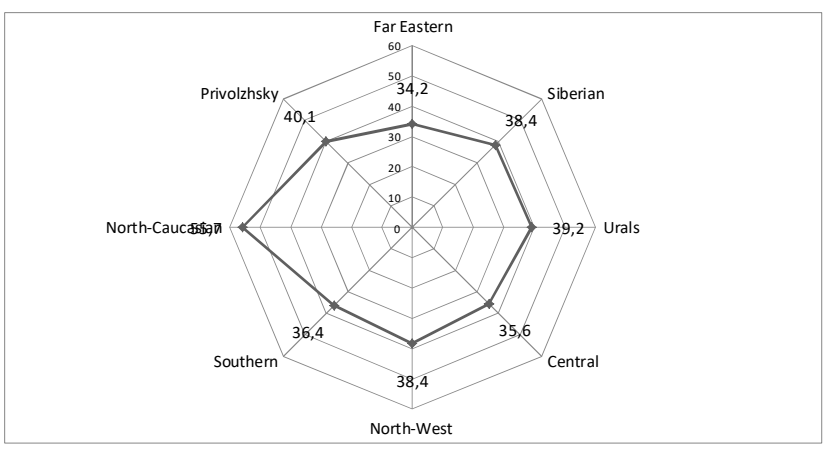

Fig. 3.The share of youth (15-29 years of age) in the total number of unemployed in the federal districts of the Russian Federation, 2016,\% (constructed according to [2]).

The risks to sustainable employment are increasing in the crisis periods for economy. According to international practices, in the post-crisis period the youth segment demonstrates much slower recovery on the labor market. Recovery of the new proportion goes on under less security for jobs, risks of shifting into informal economy sector, fall in the rate of real wages, and barriers for youth employment in the formal sector. It is the youth segment which suffers most in the period of economic instability across all the regions, and goes through a sharp rise in unemployment rate. For example, the unemployment rate among persons between 15 and 19 years of age reached its maximum in 2010 and 2014, i.e. $31.8 \%$ and $33.1 \%$ respectively (Fig. 4 ).

Investigations show that young people are exposed to higher risks in terms of employment barriers in the cases when they enter into labor markets at younger ages, have low educational level, or reside in small towns. Basically, all the regional markets are facing similar tough labor market conditions. This tendency manifested itself to a highest degree in the framework of gender discrimination.

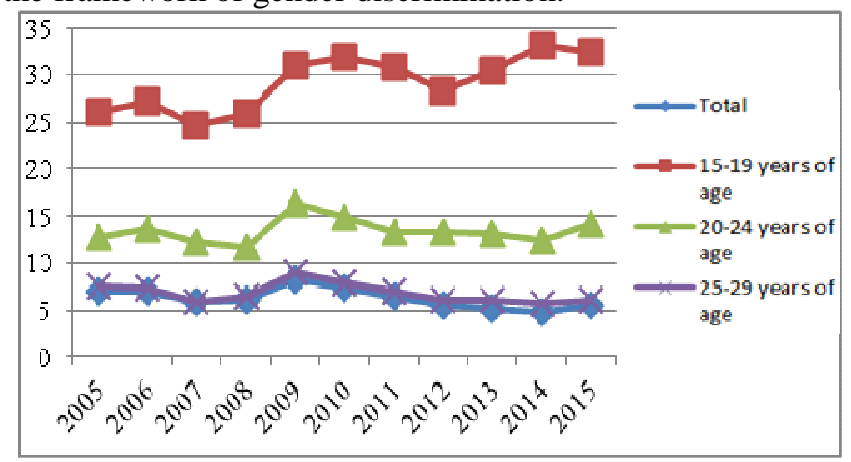

Fig. 4. - Youth unemployment rate by age group, \% [2].

The differences revealed in unemployment rates between various age groups closely correlate with educational level issues. On the one hand, educational level determines priorities in employment for the persons between 15 - 19 and 20-24 years of age, on the other hand, education secures from layoff risks the young workers at 25-29 years of age [4]. The biggest number of young people struggling with their unemployment rate is among persons of all age groups with general secondary education. According to statistics, dependence of unemployment risks on educational levels grows with a person's age. The highest unemployment rate among young people having general secondary education is for the age group from 15 to 19.

Indicators demonstrating the status of young people on the regional labor markets are as follows: youth unemployment rate, rate of young people from the "NEET" group, tension rate in the given market segment, rate of young people having long-term labor contracts, employment rate in the informal sector, and the Duncan Index. The latter characterized the discrepancy between the qualification of a young worker and his position / occupation. The provided estimates show that the Duncan Index value on the youth labor market in Russia was highest in 2007 (19.5\%).

In the recent years the dynamics of the Duncan Index has been positive, which demonstrates sustainability on the youth labor market. Regarding the youth in the informal sector, we should emphasize that in 2015, the given indicator for persons between 15 and 19 years of age was at $49.6 \%$, for the age group of 20-24 it was at 25\%, and for the 25-29 age group it was at $20.4 \%$. However, calculation of the given indicators for the regional areas is challenging due to insufficiency of statistical data.

We assume that investigation of qualitative characteristics of youth employment in the various regions must be conducted using a wide range of data, such as employment and unemployment factors, income level, labor security, engagement into new employment forms and social dialogue, and opportunities for career enhancement, i.e. the indicators which reflect the conditions for decent work opportunities declared and promoted by the International Labor Organization on the global and national levels. We assume the conducted comparative analysis of the regional labor markets would be more fruitful using the index "shortage of decent labor for youth".

This index may be created in the format of the weighted average, including the rate of employed youth with low income, the rate of unemployed youth, the rate of youth with no education or jobs (from 15 to 24 years of age) in the total number of population of the respective age group, the rate of employed youth with outside to normal working hours, the rate of young people with jobs not satisfying sanitary regulations and causing risks for health and safety. Estimation of the given index is challenging due to lack of official statistical data relating the youth employment segment. Let us consider the issues of youth unemployment in the regions based on the available statistics.

\section{RESULTS AND DISCUSSION}

Great variations in youth unemployment rates between the regions are an essential distinguishing feature of the labor market in Russia. Therefore, the analysis of youth labor markets based mostly on the average rates across Russia evens the angles of the problem and covers up an almost tenfold gap between unemployment rates across the various regions [5].

Availability of jobs for youth as an important component of employment quality varies across the regional labor markets. The biggest disengagement from the labor force among the entities of the Russian Federation is found in the 
North Caucasian Federal District with the maximum rate at $25.1 \%$ in 2010 . Statistical evidence of different percentage of unemployed amid youth are observed by federal regions and within federal regions. For example, in Privolzhsky Federal District at higher risk for permanent disengagement from labor market are youth ages 20-29 in Republic of Bashkortostan, the lowest disengagement rate is in Republic of Tatarstan, whereas Saratov Oblast demonstrates the average rate compared to other regions in the given district. At the same time, unemployment percentage among the youth ages 15-19 reaches its peak values across all the regions in the district. Exclusions are observed in Saratov and Orenburg Oblasts.

We have classified the regional labor markets in the Russian Federation by the index of vulnerable employment, i.e. the unemployment rate for youth ages 20-29 into 5 groups (Table 1).

TABLE 1. GROUPS OF REGIONAL LABOR MARKETS IN THE RUSSIAN FEDERATION UNDER YOUTH UNEMPLOYMENT RATE (2029 years)

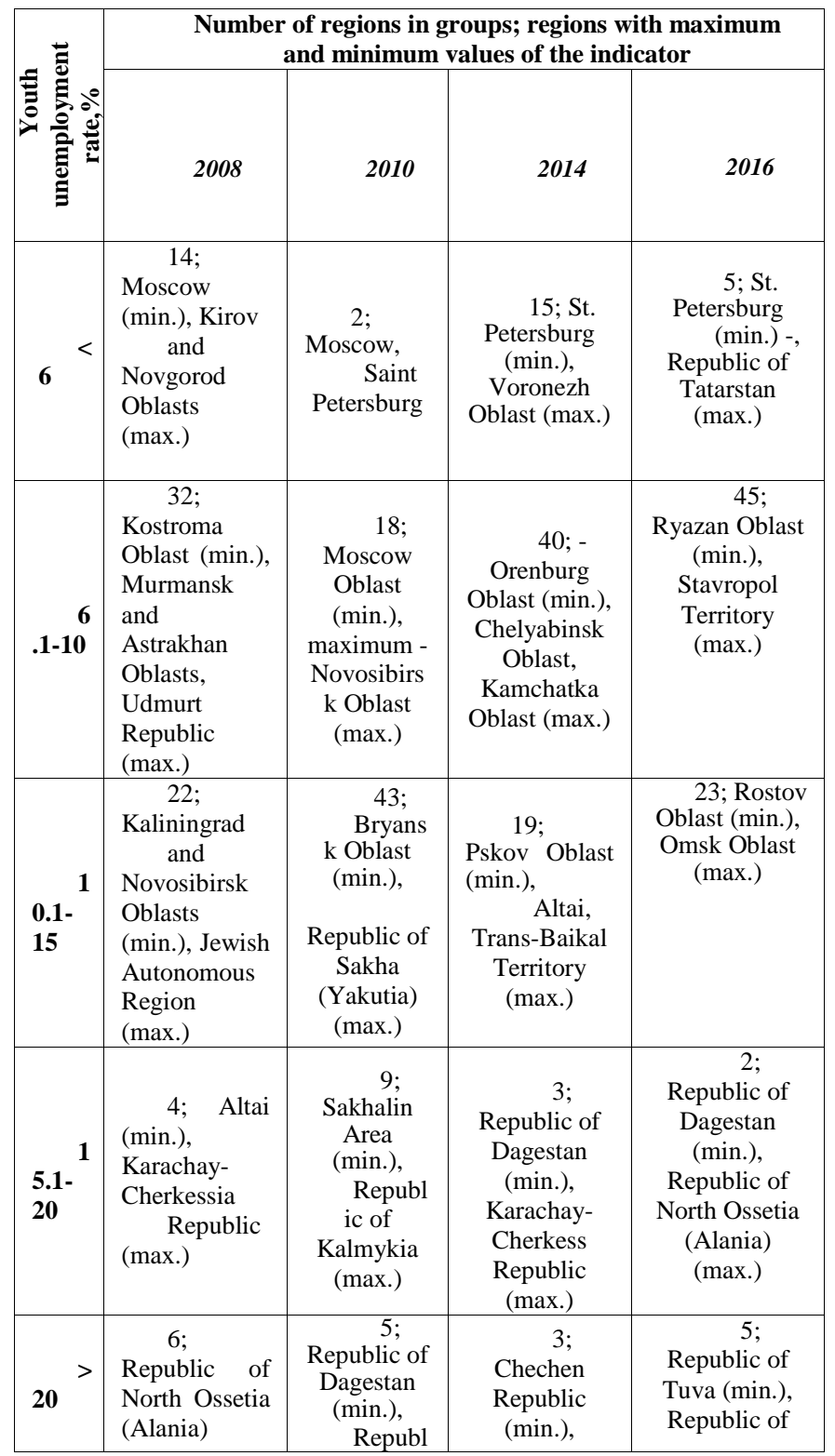

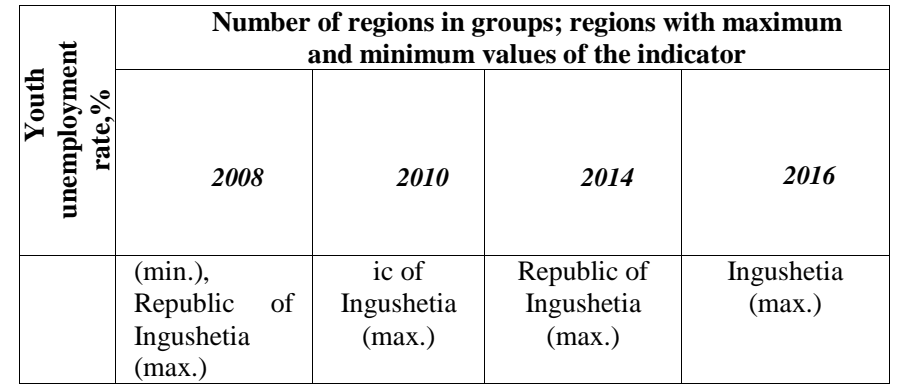

Figure 5 demonstrates the changes in the number of regions within the groups arranged in accordance with the unemployment youth rate for persons between 20 and 29 years of age.

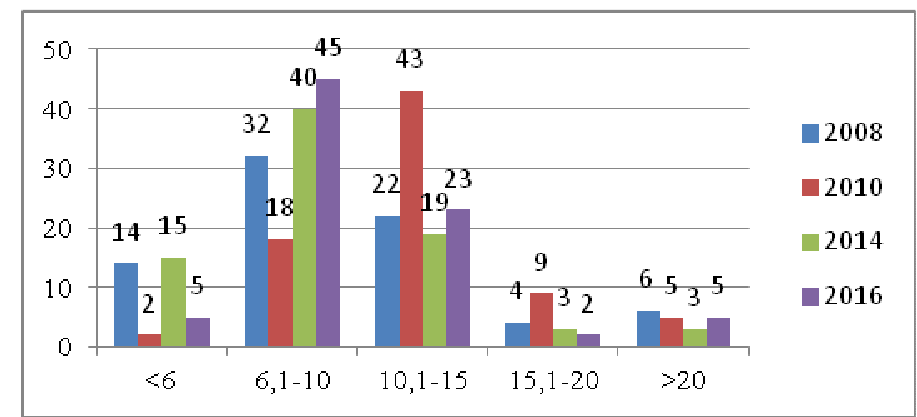

Fig. 5. - Number of regions in groups by youth unemployment rate at 2029 years of age.

\section{CONCLUSION}

Classification of regions by youth unemployment rate allows us to conclude that the number of regions with youth disengagement under $6 \%$ are characterized by offering young people the most favourable conditions to enter the job market. Consideration of the current trends relating youth employment opportunities on the regional levels allows us to emphasize that the major portion of regional labor markets fall under the second or third youth cohorts within the whole period under study. Vulnerable employment shares are highest for youth in the regional labor markets falling under the fifth cohort (with unemployment rate over 20\%). We can observe significant differences between key indicators of youth employment and indicators of decent work both by districts and within federal districts.

The conducted analysis provides evidence that in 2016, as compared to 2008, there was a tendency towards a rise in the unemployment rate among youth ages 20-29 in the following regions: Vladimir, Ivanovo, Tver, Tula, Vologda, Novgorod, Kirov, Samara, Chelyabinsk, Magadan, Sakhalin, Murmansk, Orlov, and Astrakhan Oblasts, Krasnodar Krai, Republic of Mordovia, and others.

However, within the same period, the trend is clearly towards increasing employment rates in the following regions: the Penza, Belgorod, and Volgograd Oblasts, Republics of Tatarstan, Mariy-El, Mordovia, Chuvash, Perm Krai, Nizhny Novgorod, Novosibirsk, Kemerovo, and Kaliningrad Oblasts, Kamchatka Krai, Primorsky Krai, the Khabarovsk Krai, the 
Arkhangelsk Oblast, Republic of Karelia, Amur Region, and others.

To demonstrate a positive tendency, we can emphasize an increase in the number of regions related to the second cohort (with youth unemployment rate at $6,1-10 \%$ ), and decrease in the number of regions related to the fourth cohort (with youth unemployment rate at $1,5-20 \%$ ). However, we can observe poor changes in the structure of the fifth cohort of the labor markets struggling with high unemployment rates among youth, which is a matter of serious concern.

Generally, we should emphasize that the current situation with youth employment in Russia on the level of federal districts generates scarce sustainability, i.e. sustainability related not only to jobs or income, but also to further career opportunities. Subsequently it is worthwhile investigating youth employment dimensions by estimating the indicators in terms of regional groups, and taking into account their specifics and current trends, finding out transitions between the groups, in order to specify the tactics and strategy risks arising on youth labor markets.

Opportunities and barriers to sustainable youth employment in the regions are determined by manifold and multilevel factors, which can be classified by a set of specified criteria. Currently, economic and institutional factors are essential in generation of employment on the regional levels, development of new economy sectors, digitization of employment services, institutionalization of new labor practices among youth, framing "security and flexibility" by labor market institutions, broadening competences within the framework of policies affecting youth employment, and finding new formats for interaction between social partners on the labor markets. Young people face enormous challenges on the labor markets due to mismatch between supply and demand related to professionalism and qualification levels.

The report "Analysis of corporate practices in the area of youth employment in the Commonwealth of Independent States" [6] emphasizes that employment security for young people is linked to enhancing skilled job creation, which, in its turn, is determined by the quality of entrepreneurship environment.

The current situation in the labor market determines the necessity to implement not only traditional employment policies, but also look for non-standard attitudes removing barriers to faster job creation. The format "policy-programmepromotion-partnership" is considered as most promising in terms of regulating youth segments of the labor market in the regions.

When analyzing the trends in enhancing youth employment opportunites, it is vital to take into account the long-term effect from the ongoing process of restructuring employment policies, including "intellectualization" and "informatization" policies affecting primarily the youth segment across the regions. In the current conditions, vulnerable employment will be increasingly influenced by the countercyclical and structural policies acting on the regional labor markets.
Ensuring sustainable employment presupposes development of partnership in a given area by involving social partners into the given field, by cementing public-private collaboration and relations between the state employment offices and private employment agencies, or non-profit organizations. One of the major trends of creating sustainable employment for youth is connected with widening a variety of programmes and possibilities for their selection, focusing on the target youth segments (differentiated by career items, supply-and-demand equilibrium in terms of professionalism and qualification, places of residence, occupation, health conditions, status on the labor market, etc.). In our view, the package of programmes targeted for youth labor markets in the regions must be characterized by "mobility" and their makeup, and reflect economic development strategies of various regions and single-industry towns.

Conditions of youth segment in the regional labor markets to a certain degree depend on improving the technologies applied for promotion of the relevant programmes and measures. Promotion must be coupled with the advisory data applied to youth entrepreneurship programmes designed for the various subject groups in the youth labor market. Additionally, promotion should refer to innovative labor practices, patterns of decent work, practices of social responsibility of business, and youth corporate policies.

Some researchers abroad, considering an "alternative" employment policy, prove the importance of efficiency in the long-term policy focused on development of competences and skills, which actually allow subjects of the labor market manage their income and ensure the living standards [7].

The digital economy can facilitate solving the problems with lack of decent labor in terms of improving employment quality, and creating new jobs on the global and regional levels. However, equal distribution of benefits of the digital economy growth may pose serious problems. It is essential to develop a range of measures to ensure sustainable youth employment in the regions. These measures must take account the best practices in implementing the following tasks:

using business cases for investigation of long-term trends in the youth segment of regional labor markets;

enhancing career planning technologies targeting young people at various educational levels;

considering regional labor market requirements in order to implement educational programmes and develop new educational standards;

promoting programmes designed and targeted at training the necessary work experience and competences;

designing programmes to support youth entrepreneurship in the regions.

In the report on "Youth Policy Strategies until 2015", there is an increasing emphasis on economic competition advantages for youth. The given task involves development of the labor potential, creation of high-skilled jobs, building resilience to economic changes, development of labor productivity and professional competences, minimizing 
outflow and losses of human capital, ability to realize career ambitions under conditions bringing new uncertainties [8].

Thus, dynamic development of the youth employment system, together with its functional and structural dimensions, implies defining new vectors for the management of the system on the regional levels.

\section{References}

[1] Clark K.B., Summers L.H. The Dynamics of Youth Unemployment // The Youth Labor Market Problem: Its Nature, Cases and Consequences / R. Freeman, D. Wise (eds.). University of Chicago . - 1982. - Press. P. 199-234.

[2] Work and Employment in Russia - 2015. [Trud i zanyatost' v Rossii 2015] -URL: http://www.gks.ru/bgd/regl/b15_36/Main.htm

[3] Rusanovskii, V.A., Blinova T.V., Bylina S.G. Youth unemployment in Russia: inter-regional comparisons [Molodezhnaya bezrabotitsa $\mathrm{v}$ Rossii: mezhregional'nye sopostavleniya] // Bulletin of the Saratov State Social and Economic University [Vestnik Saratovskogo gosudarstvennogo sotsial'no-ekonomicheskogo universiteta]. 2014. № 5 (54). - C. 30 .

[4] Cherednichenko G.A. Youth employment and vocational and educational trajectories [Zanyatost' molodezhi i professional'no- obrazovatel'nye traektorii] // Sociological journal [Sotsiologicheskii zhurnal]. 2010. - № 3. - C. 58.

[5] Youth labor market: assessment and modeling of interregional differences: monograph [Molodezhnyi rynok truda: otsenka i modelirovanie mezhregional'nykh razlichii: monografiya] / T.V. Blinova, S.A. Andryushchenko, S.G. Bylina i dr. - M: OOO «Izdatel'skii dom KDU», 2016.

[6] Analysis of corporate experience in the field of youth employment by the example of a number of CIS countries (Azerbaijan, Armenia, Kazakhstan, Russia) [Analiz korporativnogo opyta v oblasti zanyatosti molodezhi na primere ryada stran SNG (Azerbaidzhan, Armeniya, Kazakhstan, Rossiya)] / The Decent Work Technical Support Team and the ILO Office for Eastern Europe and Central Asia. - Moscow: ILO, 2016. [Gruppa tekhnicheskoi podderzhki po voprosam dostoinogo truda i Byuro MOT dlya stran Vostochnoi Evropy i Tsentral'noi Azii. Moskva: MOT, 2016.]

[7] Bredgaard Th., Halkjær J. Lystlund. Employers and the Implementation of Active Labor Market Policies //Nordic journal of working life studies,Vol. 6-1,March 2016.

[8] Youth Development Strategy of the Russian Federation for the period up to 2025 [Strategiya razvitiya molodezhi Rossiiskoi Federatsii na period do 2025 goda]. ttps://fadm.gov.ru/mediafiles/documents/document/98/ae/98aeadb57771-4e5b-a8ee-6e732c5d5e84.pdf 